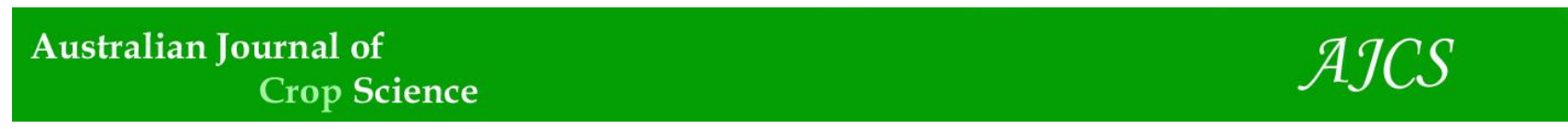

AJCS 12(07):1090-1098 (2018)

ISSN:1835-2707

doi: 10.21475/ajcs.18.12.07.PNE1013

\title{
Differential susceptibility of morning glory (Ipomoea and Merremia) species to residual herbicides and the effect of drought periods on efficacy
}

\author{
Nagilla Moraes Ribeiro, Beatriz Alexandre Torres, Stephanie Karen Ramos, Paulo Henrique Vieira dos \\ Santos, Camila Tonelotti Simões, Patricia Andrea Monquero*
}

FAPESP scholarship, Department of Natural Resources and Environmental Protection, São Carlos University, Araras, São Paulo State, Brazil

*Corresponding author: pamonque@ufscar.br

\begin{abstract}
The plants commonly known as morning glory belong to the genera Ipomoea and Merremia and are among the most important weeds in Brazil. Greenhouse studies were conducted in 2016/2017 to compare the susceptibility of different morning glory species - Ipomoea quamoclit, I. nil, I. hederifolia, I. triloba, Merremia aegyptia, and M. cissoides to soil-applied herbicides and to evaluate the effectiveness of these herbicides after periods of drought. In the first experiment, to evaluate the efficacy of each herbicide at pre-emergence stage, a fully randomized 6 (doses) $\times 6$ (species) factorial experimental design with six replicates was used. The herbicides tebuthiuron $\left(3,200 ; 1,600 ; 800 ; 400 ; 200\right.$ and $0.0 \mathrm{~g}$ a.i ha $\left.{ }^{-1}\right)$, amicarbazone $\left(2,100 ; 1,050 ; 750 ; 375 ; 187\right.$ and $\left.0.0 \mathrm{~g}^{2} . \mathrm{i} \mathrm{ha}^{-1}\right)$, sulfentrazone $\left(1,200 ; 600 ; 300 ; 15075\right.$ and $0.0 \mathrm{~g}$ a.i ha $\left.{ }^{-1}\right)$, mesotrione $\left(240 ; 120 ; 60 ; 30 ; 15\right.$ and $0.0 \mathrm{~g}$ a.i ha $\left.{ }^{-1}\right)$, saflufenacil (200; 100; 50; 25; 12 and $0.0 \mathrm{~g}$ a.i ha $^{-1}$ ), and imazapic (360; 180; 90; 45; 22 and $0.0 \mathrm{~g}$ a.i ha ${ }^{-1}$ ) were applied. Ipomoea hederifolia, I. nil, and $I$. quamoclit were most susceptible to saflufenacil; I. triloba and $M$. cissoides were most susceptible to tebuthiuron; and $M$. aegyptia was most susceptible to amicarbazone. Therefore, the best herbicide treatment depends on the species of morning glory. In the second experiment, to determine the effectiveness of herbicides after periods of drought, the treatments were arranged, for each herbicide, in a fully randomized $6 \times 5$ factorial design with four replicates, six species of morning glory, and five sowing times after periods of drought $(0,15,30,45$, and 60 days after application (DAA) of the herbicides) relative to the application of the amicarbazone $\left(1,050 \mathrm{~g}\right.$ a.i ha $\left.{ }^{-1}\right)$, imazapic $\left(180 \mathrm{~g}\right.$ a.i ha $\left.{ }^{-1}\right)$, mesotrione (120 g a.i ha $\left.{ }^{-1}\right)$, saflufenacil $\left(100 \mathrm{~g}\right.$ a.i ha $\left.{ }^{-1}\right)$, sulfentrazone $(600$ $\mathrm{g}$ a.i $\left.\mathrm{ha}^{-1}\right)$, and tebuthiuron $\left(1,600 \mathrm{~g}\right.$ a.i ha $\left.{ }^{-1}\right)$. Herbicide effectiveness after periods of drought began to decrease after 15 days for saflufenacil; 30 days for imazapic, mesotrione, and tebuthiuron; 45 days for amicarbazone; and 60 days for sulfentrazone. Preemergence application of amicarbazone and sulfentrazone exhibited consistent efficacy during the drought periods, satisfactorily controlling the species of morning glory.
\end{abstract}

Keywords: morning glory, chemical control, drought, residual. Abbreviation: a.i - active ingredient.

\section{Introduction}

Invasive species of the Convolvulaceae family are highly competitive weeds, especially those belonging to the genera Ipomoea and Merremia that are commonly known as morning glory. These plants are native to South America and reproduce by seeds with approximately 50 to 300 diaspores per plant, of which only a small percentage germinate quickly while the others germinate randomly over time (Kissmann and Groth, 1999). These plants are problematic due to their climbing growth habit and twining stems and vines, which wrap themselves around crop culms and establish themselves at the apex of plants, which negatively affects photosynthetic efficiency and impedes mechanized harvesting by clogging the harvester (Correia; Durigan, 2004; Christoffoleti et al., 2006). The intensity of the losses caused by weeds varies according to which species are in the crop production area. Plants of the Ipomoea and Merremia genera are morphologically similar and predominantly known by their common names, which hinders correct identification and may prejudice the proper choice of herbicide (Christoffoleti et al., 2007). Within the Ipomoea and Merremia, species such as Ipomoea triloba, $I$. hederifolia, I. nil, I. quamoclit, Merremia cissoides, and $M$. aegyptia are particularly important weeds (Correia and Durigan, 2004; Monquero et al., 2008a; Monquero et al. 2011). Over time, increased infestation by species of climbing plants, such Ipomoea and Merremia, has been observed in areas of sugarcane cultivation, and it is possible that the maintenance of sugarcane straw on the soil surface creates an environment that is more favorable for seed germination and the development of such plants due to the lower daily temperature range, greater conservation of soil moisture and soil chemical and physical improvement. Furthermore, mechanized harvesting of sugarcane facilitates the spread of morning glory seeds, either in the same area or from one area to another (Correia, 2016). A phytosociological survey of infested communities in 28 
sugarcane agroecosystems indicated the presence of different morning glory species ( $I$. nil, $I$. quamoclit, $I$. hederifolia, I. triloba, I. purpurea, and $M$. cissoides), and in 17 areas, the species were present in sufficient quantities to be considered important (Kuva et al., 2007). It has been reported that competition with Ipomoea spp. can reduce sugarcane production by $36 \%$ (Bhullar et al., 2012). Carvalho et al. (2014) observed that allowing I. hederifolia plants to coexist with corn crops reduced the growth of and accumulation of macronutrients by the corn plants with negative consequences for crop productivity and serious disturbances during mechanical harvesting when the weed is fully developed. In soybean, one Ipomoea plant $\cdot \mathrm{m}^{-2}$ can reduce the yield by approximately $26 \%$, and the negative impact of $I$. purpurea on soybean growth and yield is greater than that of I. grandifolia (Pagnoncelli et al., 2017). Although they possess similar characteristics, species within a genus - and in the case of morning glory, different genera - may differ in their susceptibility to an herbicide and thus may not respond uniformly to its application (Christoffoleti et al., 2006; Orzari et al., 2013; Campos et al., 2009). Therefore, species-specific recommendations may be necessary. Doseresponse curves are often used to quantify plant sensitivity to an herbicide (Seefeldt et al., 1995) and can be developed from herbicide bioassays. Tests of the susceptibility of the species $I$. quamoclit, I. triloba, and $M$. cissoides to the herbicides sulfentrazone and amicarbazone have indicated that $I$. quamoclit is the most sensitive species, and the order of the susceptibility of tested species to sulfentrazone was $I$. quamoclit $>M$. cissoides $>$. triloba, whereas for amicarbazone, the order was I. quamoclit>l. triloba $>M$. cissoides (Campos et al., 2009). The herbicides imazapic (sprayed pre-emergence in the dry and semi-wet seasons) and mesotrione alone (applied post-emergence in the wet season) in sugarcane culture resulted in a lower control percentage of $M$. aegyptia but excellent control of $I$. hederifolia, I. nil, I. quamoclit and I. triloba (Correia, 2016).

The need to control these species during winter, a period characterized by a lack of water, is common, especially in the Southeast Region of Brazil. Non-photodegraded herbicides with a low tendency toward volatility, high solubility in water, low sorption to soil colloids, and a primarily microbial degradation route generally perform satisfactorily when applied during the dry season (Monquero et al., 2008b; Carvalho et al., 2006). Thus, it is important to evaluate the effect of drought periods on the ability of herbicides to control morning glory species. The objectives of this work were to estimate the susceptibility of different morning glory species (I. triloba, I. nil, I. hederifolia, $I$. quamoclit, $M$. aegyptia, and $M$. cissoides) to residual herbicides applied during the pre-emergence stage and to determine the effect of drought periods on the efficacy of these herbicides.

\section{Results and Discussion}

Experiment 1: Susceptibility of different morning glory species to residual herbicides applied during the preemergence stage

The tested morning glory species showed high susceptibility to the herbicide amicarbazone; I. hederifolia only had lower susceptibility than the others at a dose of $187 \mathrm{~g}$ a.i ha ${ }^{-1}$ (Fig.
1), but at the commercial dose, this difference disappeared. Similar to previous results, the herbicide amicarbazone, when applied during the pre-emergence stage at doses of $1,050,1,225$, and $1,400 \mathrm{~g}$ a.i ha ${ }^{-1}$, efficiently controlled $I$. triloba, I. hederifolia, I. nil, I. quamoclit, and $M$. cissoides (Carvalho et al., 2011). Doses of imazapic at or above $90 \mathrm{~g}$ $\mathrm{ha}^{-1}$ provided effective control of I. triloba, M. aegyptia, and $M$. cissoides, which only demonstrated decreased susceptibility at a dose of $22 \mathrm{~g}$ a.i ha ${ }^{-1}$ (Fig. 1).

The dry biomass weight data indicate the negative effects of herbicides, even at doses lower than the commercial rate. For imazapic, the biomass data indicate that only I. triloba experienced levels of control lower than those of the other species below the commercial dose; a reduction in biomass greater than $80 \%$ was achieved at or above the commercial dose (Fig. 1).

Seeking to evaluate the control of $I$. nil using the herbicides amicarbazone $\left(1,050 \mathrm{~g}\right.$ a.i ha $\left.{ }^{-1}\right)$, imazapic (122 g a.i ha ${ }^{-1}$ ), and sulfentrazone (600 $\mathrm{g}$ a.i ha ${ }^{-1}$ ), Azania et al. (2009) observed excellent control by both herbicides at 90 days after application (DAA), but unlike the results observed in this study, imazapic was considered to be ineffective, resulting in less than $65 \%$ control. In this case, the herbicide may have undergone environmental degradation that reduced its efficacy. For the species I. grandifolia, I. hederifolia, I. nil, I. purpurea, I. quamoclit, and M. cissoides, Lucio et al. (2011) found control percentages of $25 \%$ and $53 \%$ (in the presence and absence of straw, respectively) at 21 DAA and $80 \%$ at 42 DAA.

Sulfentrazone was efficient at controlling the tested species, reinforcing the susceptibility of $I$. nil and $I$. quamoclit, even at the lowest dose used; these species were fully controlled by half the commercial dose and above (Fig. 2). At lower doses, a marked reduction in the dry biomass of the aerial portions of the plants was observed for all the tested species. At lower doses of tebuthiuron, I. nil and $I$. hederifolia demonstrated less susceptibility than the other tested species, but when using half the commercial dose or more, all species were effectively controlled (Fig. 2). The biomass data corroborate the finding of a lower percentage of control for I. hederifolia and I. nil at the lowest doses tested (Fig. 2).

These results agree with those obtained by Silva et al. (2015) in sugarcane straw for the herbicides sulfentrazone (800 g a.i ha $\left.{ }^{-1}\right)$, hexazinone (187.5 g a.i ha $\left.{ }^{-1}\right)$, and amicarbazone $\left(1,050 \mathrm{~g}\right.$ a.i ha $\left.{ }^{-1}\right)$ as well as their combinations at different doses for the control of morning glory species. According to the authors, $M$. aegyptia was efficiently controlled with the herbicides amicarbazone (99.99\%) and sulfentrazone $(88.00 \%)$ but less efficiently controlled with hexazinone $(75 \%)$.

The control of $M$. cissoides, I. triloba, and I. quamoclit by the pre-emergence application of the herbicide sulfentrazone (800 $\mathrm{g}$ a.i $\mathrm{ha}^{-1}$ ) was effective and persisted until 35 DAT. The herbicide amicarbazone $\left(980 \mathrm{~g} \mathrm{ha}^{-1}\right)$ also adequately controlled the three weed species, except at 15 DAA when the maximum level of control stabilized at $80 \%$ (Campos et al., 2009).

At half its commercial dose, the herbicide mesotrione controlled more than $80 \%$ of the tested samples, but $M$. cissoides was controlled less than the other tested species at a dose of $31 \mathrm{~g}$ a.i ha ${ }^{-1}$. Marked reductions in dry biomass were observed, which indicates effective control by the 
herbicide (Fig. 3). By inhibiting p-hydroxyphenylpyruvate dioxygenase (HPPD)-inhibiting triketone, the mesotrione herbicide depletes plastoquinone levels, thus reducing carotenoids. This leads to bleaching symptoms followed by necrosis of the meristematic tissue within 3 to 5 days of application and then throughout the entire plant by approximately 2 weeks (Wichert et al., 1999).

Saflufenacil had a similar effect on the tested species at all doses and resulted in a high percentage of control; dry biomass was greatly reduced at $15 \mathrm{~g}$ a.i ha ${ }^{-1}$ (Fig. 3). Currently, the highest use rates (e.g., $>50 \mathrm{~g}$ a.i ha ${ }^{-1}$ ) of saflufenacil are for pre-broadleaf weed control in corn and sugarcane fields. Such rates provide residual control of troublesome and herbicide-resistant broadleaf weeds such as morning glories (Ipomoea spp.), tall waterhemp [Amaranthus tuberculatus (Moq.) Sauer], giant ragweed (Ambrosia trifida L.), common cocklebur (Xanthium strumarium L.), and velvetleaf (Abutilon theophrasti Medik.) (Gannon et al., 2014).

Experiment 2: Effect of drought on the efficacy of residual herbicides applied in the pre-emergence stage to different species of morning glory

After drought, the control of morning glory species by amicarbazone was reduced, but this reduction varied depending on the species. Sowing on the day of herbicide application led to efficient control (above $80 \%$ ) of all the tested species, but when sowing was performed 60 days after a period of drought, the level of control of $M$. aegyptia was approximately $80 \%$ but less than $30 \%$ for $M$. cissoides (Fig. 4). A greater reduction in the biomass of I. hederifolia, $M$. cissoides, and $I$. nil was verified for sowing 30 or more days after spraying (Fig. 4). Perim et al. (2009) verified that, regardless of the morning glory species tested (I. triloba or $M$. cissoides), amicarbazone provided total control at the studied herbicide doses $\left(700,1,050\right.$, and 1,400 $\left.\mathrm{g} \mathrm{ha}^{-1}\right)$, even when sowing was performed 21 DAA of herbicide.

Takano et al. (2015) observed that the use of amicarbazone and imazapic was effective at controlling Senna obtusifolia in soils with different textures during the dry season, but only in initial evaluations. A similar result was obtained by Giancotti et al. (2012), who found that amicarbazone was inefficient at controlling grasses subjected to 60 days of drought.

Similarly, control by the herbicide imazapic decreases during the time between application and sowing, but this decrease is more significant when sowing occurs 30 DAA or more in drought conditions, and the level of control differs among species. The species I. hederifolia, I. quamoclit, and $M$. cissoides were not controlled when sowing occurred after 60 days of drought; only mild chlorosis was verified. Greater susceptibility was confirmed for I. triloba, and control close to $60 \%$ was verified when 60 days of drought occurred after application (Fig. 6). The lowest reduction in dry biomass was observed for I. hederifolia, $M$. cissoides, and I. quamoclit (Fig. 4). Carvalho et al. (2012) observed the activity of the herbicide imazapic in soil after 90 days of drought, but the authors worked with a bioindicator plant characterized by high susceptibility.

According to Carvalho et al. (2012), the residual activity of imazapic and amicarbazone, when applied on bioindicator plants (cucumber) during different periods of the year, showed control for up to 130 days in the field when herbicide was applied in June. For applications in August (after 70 days in the field without rainfall), the control of the bioindicator by the herbicides imazapic, amicarbazone, and hexazinone was greater than $90 \%$. Imidazolinones, the chemical group to which this herbicide belongs, dissipate via microbial degradation and photolytic decomposition, especially when exposed to ultraviolet light (Mallipudi et al., 1991). Microbial activity, which is the primary route of degradation, is reduced in dry soil, so the molecule is more persistent.

The use of tebuthiuron resulted in a greater reduction in the control of M. aegyptia and I. hederifolia compared to the other species when sowing occurred 15 or more DAA; for $I$. quamoclit and $I$. triloba, this reduction was most evident when sowing occurred 40 or more DAA. When sowing was performed 60 DAA, weed control was less than $60 \%$ regardless of species. The measured biomass values indicate the distinct effects of the herbicides on the different species studied, with a smaller effect on the accumulation of biomass by $M$. cissoides and $M$. aegyptia, especially when sowing was performed later relative to application (Fig. 5). Under field conditions, Souza et al. (2008) determined that tebuthiuron would not be found in rainwater samples after a period of approximately 180 days due to its biological degradation or retention in clay particles; reduced efficacy begins 30 DAA.

Sulfentrazone resulted in a more discrete reduction in control over time; greater than $80 \%$ control of $I$. triloba and I. quamoclit and close to $80 \%$ control of $I$. nil and $I$. hederifolia were observed after 60 days. A larger reduction was observed in the control of $M$. cissoides and M. aegyptia with more time between application and sowing (Fig. 5). The data for the dry biomass of the aerial portions of the plants indicate greater reductions in $I$. triloba and $I$. quamoclit. Blanco and Velini (2005) determined the persistence of sulfentrazone 376 DAA at the lowest dose $\left(600 \mathrm{~g}\right.$ a.i ha $\left.{ }^{-1}\right)$. At the highest dose $\left(1,200 \mathrm{~g}\right.$ a.i ha $\left.{ }^{-1}\right)$, it was not possible to determine when persistence ceased, even at the last sampling time (539 DAA), and the bioindicator (beet) demonstrated the phytotoxicity of the herbicide.

Sulfentrazone is registered in Brazil for use on soybean, sugarcane, coffee, and citrus crops. It belongs to the aryltriazolinone group and has a solubility of $780 \mathrm{mg} \mathrm{L}^{-1}(\mathrm{pH}$ 7) (Rodrigues; Almeida 2015). Therefore, leaching of the herbicide from the superficial layers of the sample pot could have occurred in this study, thereby reducing control of the weeds, which were sown superficially. Moreover, the species tested are less susceptible than the bioindicator used in a previous persistence study.

Dry season application of sulfentrazone, which exhibited a long period of persistence on the crop residue before rainfall, resulted in significant losses in terms of the amount of herbicide reaching the soil, so the dose may need to be seasonally adjusted to offset these losses. However, the sensitivity of target weeds to sulfentrazone and the aspects related to selectivity should also be considered to avoid any injury to the crop in the case of early rains (Carbonari et al., 2016).

Saflufenacil only efficiently controlled weeds, regardless of species, when sowing was performed on the day of the application, and a reduction in its efficacy was observed over 
Table 1. Soil chemical and physical analyses in the experiments.

\begin{tabular}{|c|c|c|c|c|c|c|c|c|c|c|c|c|c|}
\hline P & $\mathrm{OM}$ & $\mathrm{pH}$ & K & $\mathrm{Ca}$ & $\mathrm{Mg}$ & $\mathrm{H}+\mathrm{Al}$ & Al & BS & CEC & V & Clay & Sand & Silt \\
\hline $\mathrm{mg} / \mathrm{dm}^{3}$ & $\mathrm{~g} / \mathrm{dm}^{3}$ & $\mathrm{CaCl}_{2}$ & $\mathrm{mmol}_{\mathrm{c}} / \mathrm{dm}^{3}$ & & & & $\%$ & & & $\%$ & & $\mathrm{~g} \mathrm{~kg}^{-1}$ & \\
\hline 15 & 24 & 5.1 & 2.5 & 28 & 12 & 40 & 0.4 & 42.5 & 82.5 & 52 & 660 & 150 & 190 \\
\hline
\end{tabular}

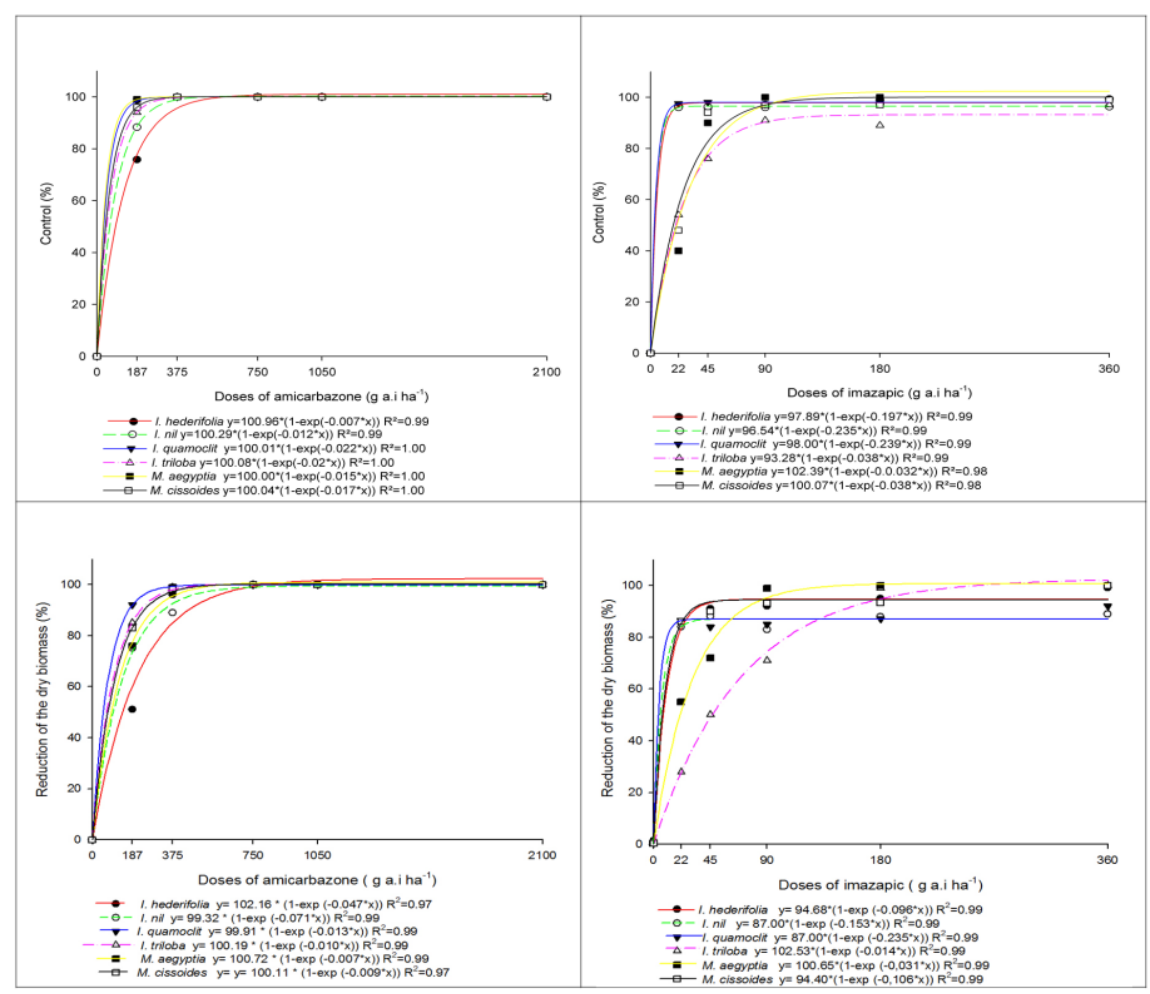

Fig 1. Control percentage and reduction in the dry biomass of the aerial part of the weeds Ipomoea hederifolia, I. nil, I. quamoclit, I. triloba, Merremia aegyptia, and $M$. cissoides at 35 days after the pre-emergence application of amicarbazone and imazapic.

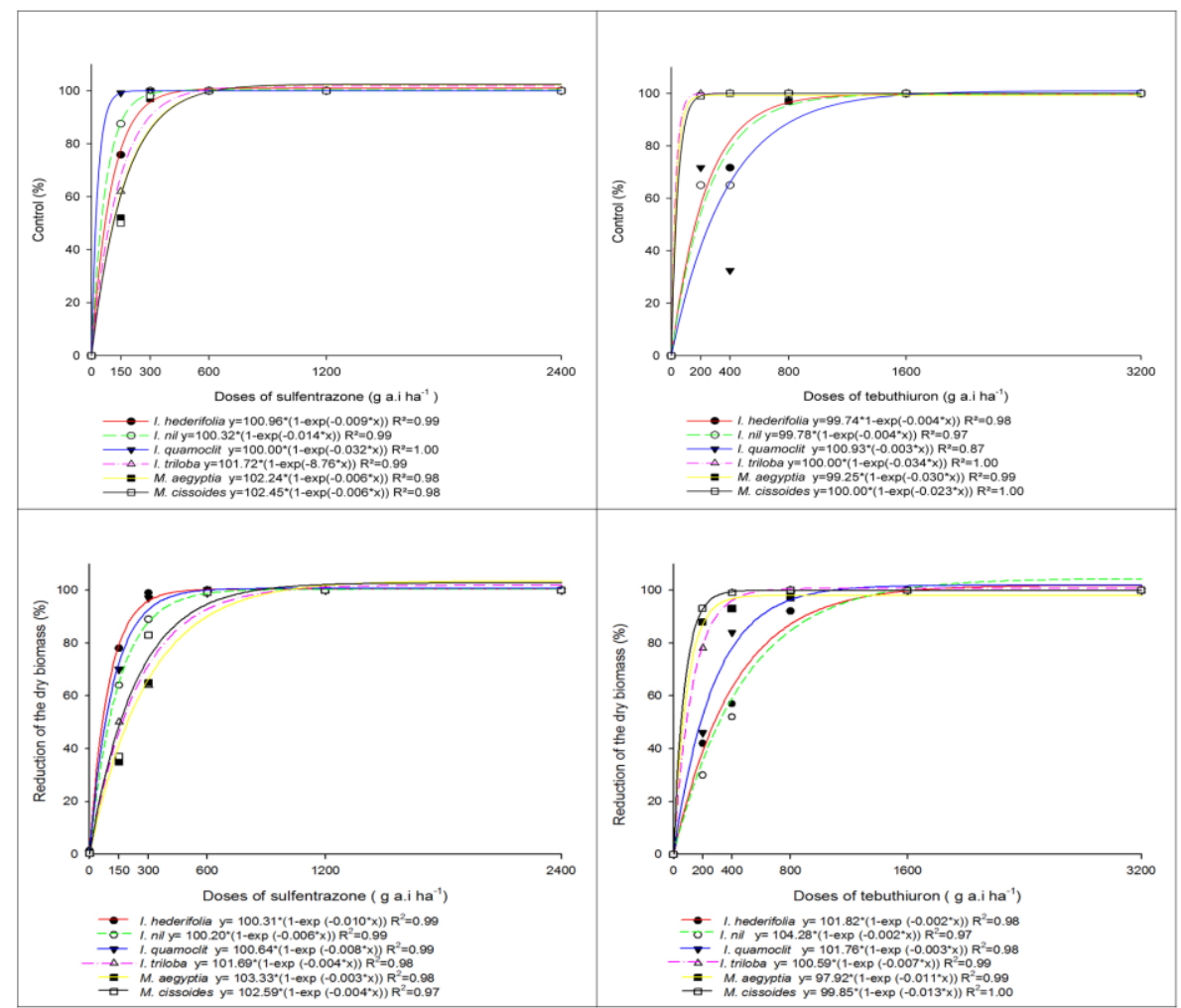

Fig 2. Control percentage and reduction in the dry biomass of the aerial part of the weeds Ipomoea hederifolia, I. nil, I. quamoclit, I. triloba, Merremia aegyptia, and M. cissoides at 35 days after the pre-emergence application of sulfentrazone and tebuthiuron. 


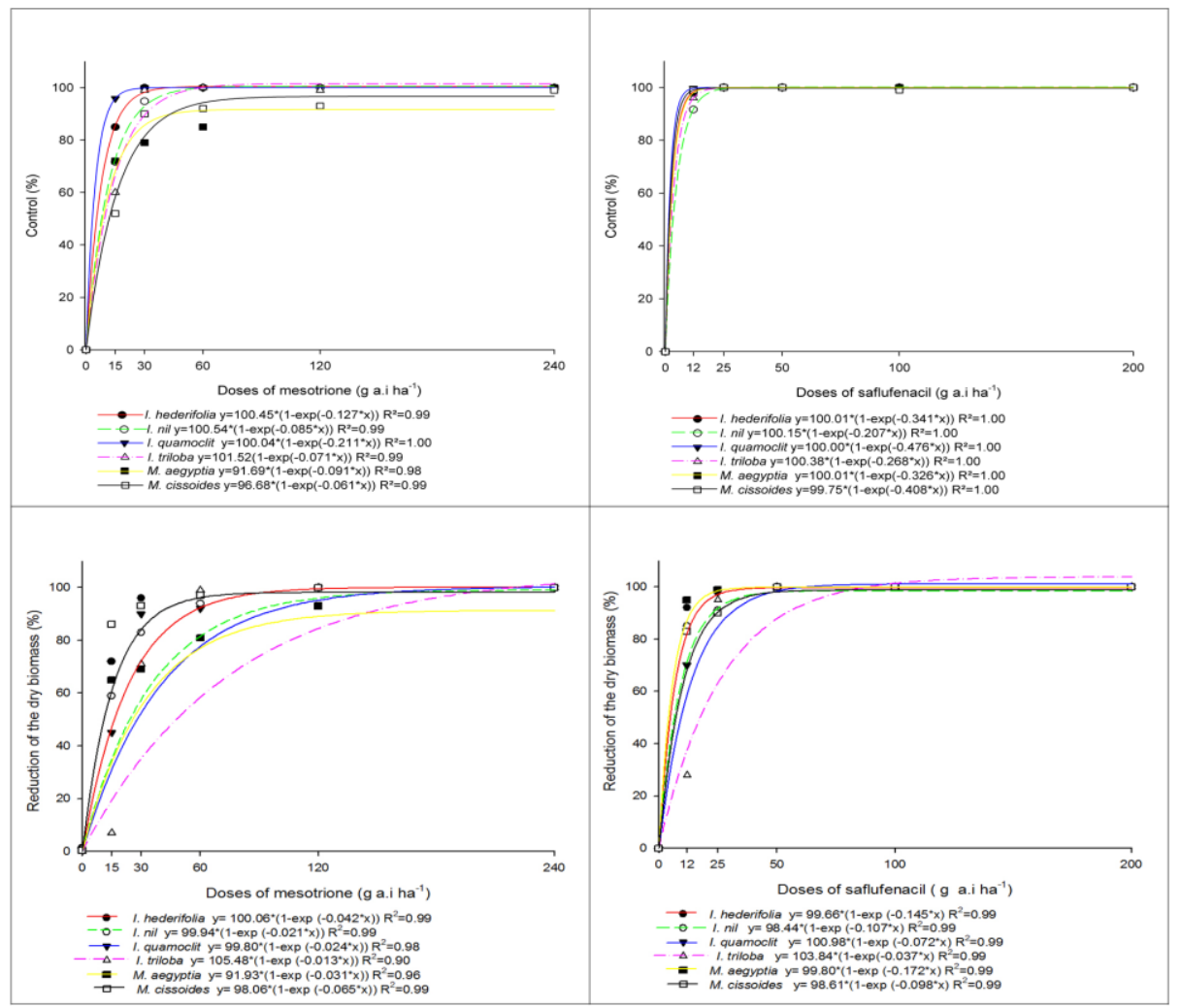

Fig 3. Control percentage and reduction in the dry biomass of the aerial part of the weeds Ipomoea hederifolia, I. nil, I. quamoclit, I. triloba, Merremia aegyptia, and $M$. cissoides at 35 days after the pre-emergence application of mesotrione and saflufenacil.

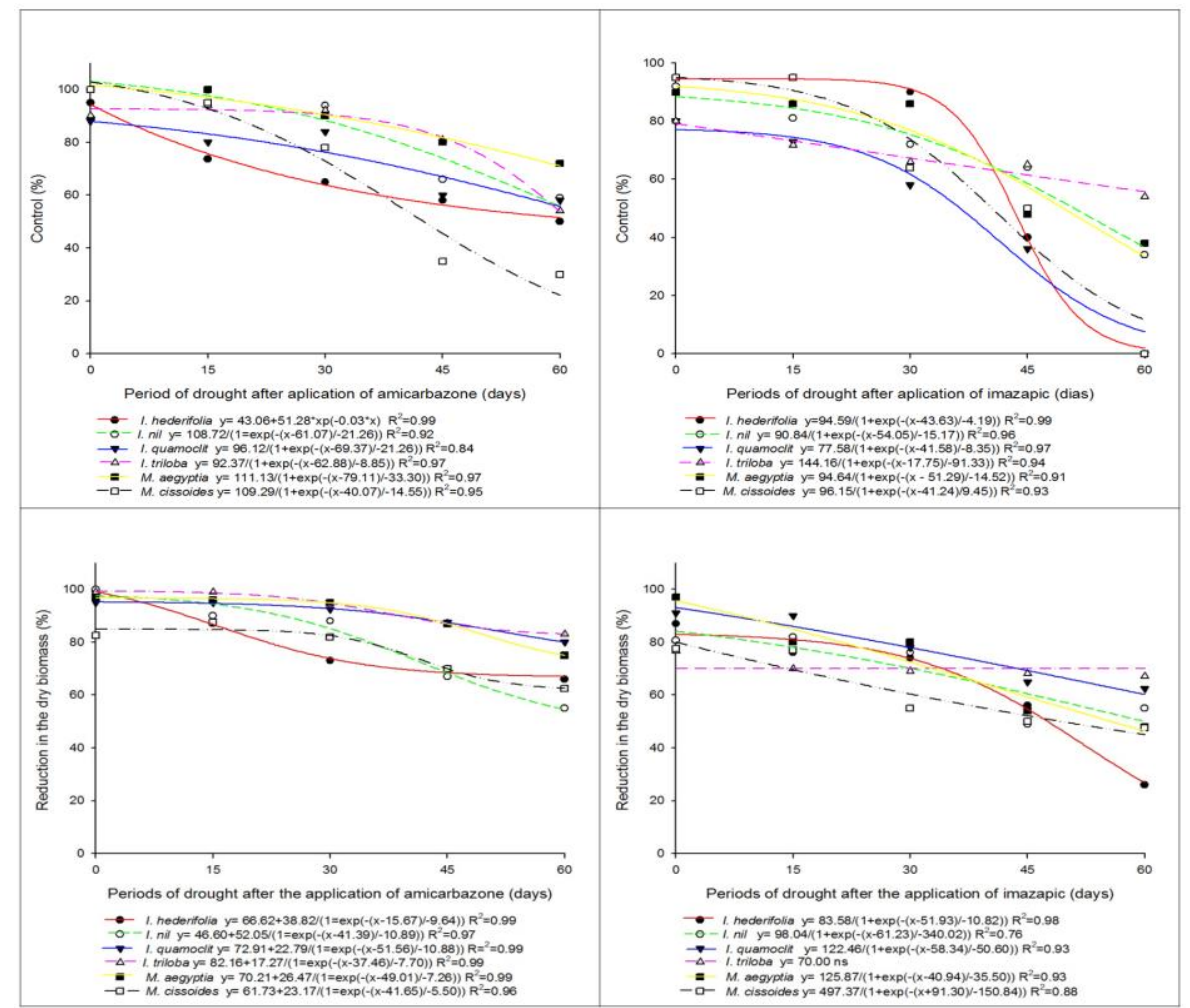

Fig 4. Control percentage and reduction in the dry biomass of the aerial portions of weeds sown at different times during drought after the application of the herbicides amicarbazone and imazapic. 


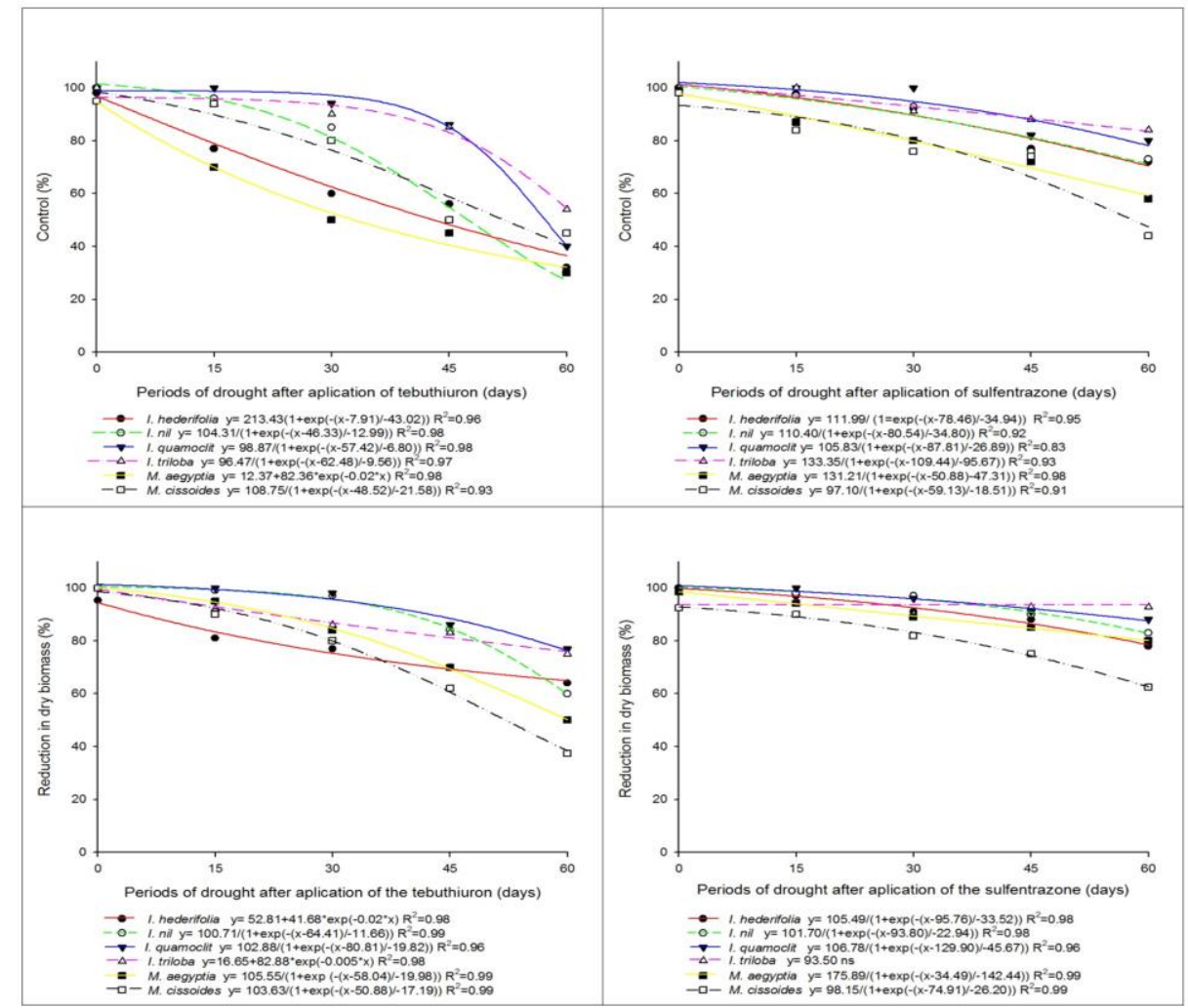

Fig 5. Control percentage and reduction in the dry biomass of the aerial portions of weeds sown at different times during drought after the application of the herbicides tebuthiuron and sulfentrazone.

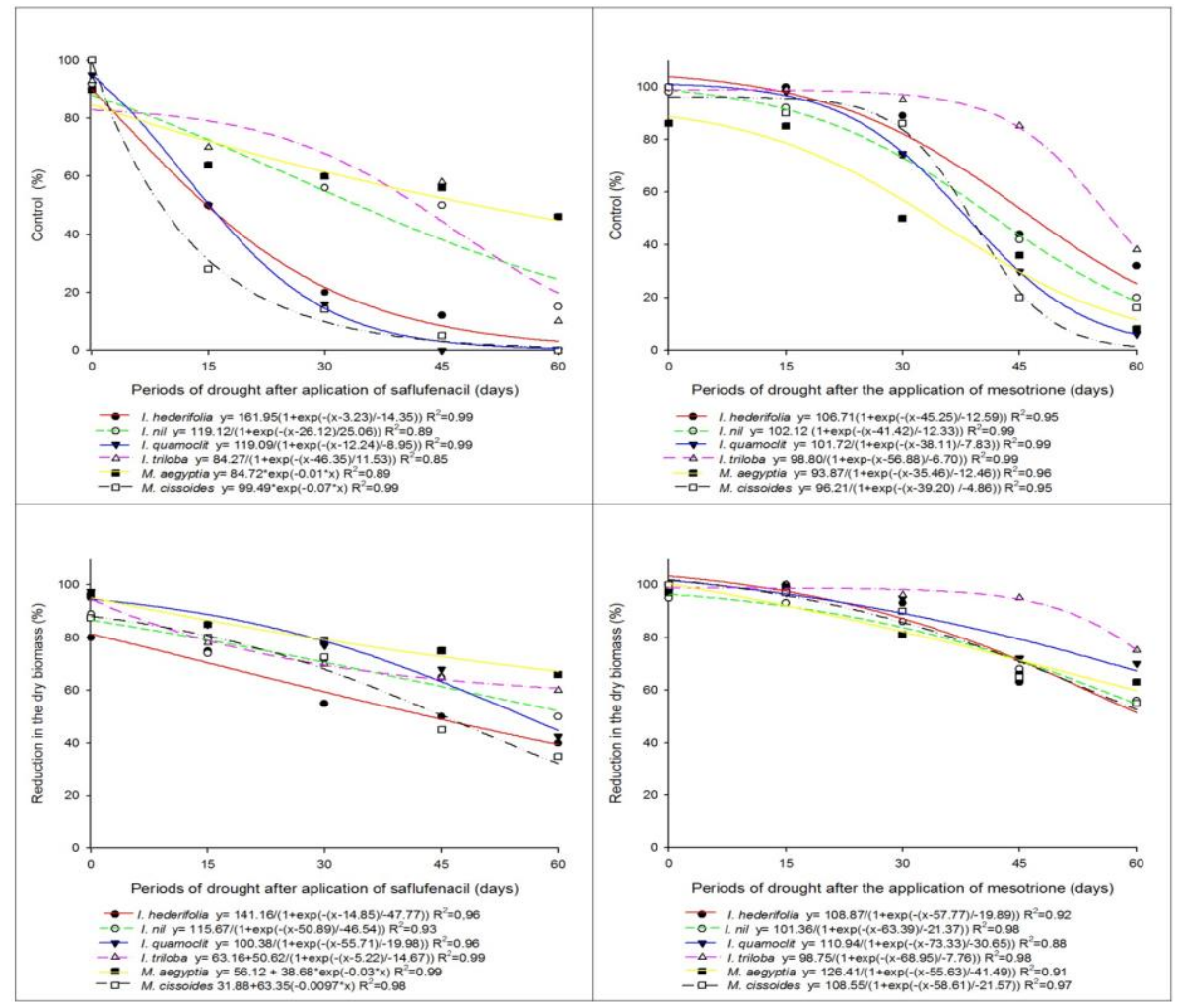

Fig 6. Control percentage and reduction in the dry biomass of the aerial portions of weeds sown at different times during drought after the application of the herbicides saflufenacil and mesotrione. 
time. The species I. hederifolia, I. quamoclit, and M. cissoides were less susceptible to this herbicide than the other species tested; a more pronounced reduction in control was observed with a longer period between sowing and application, and there were no signs of phytotoxicity when sowing was performed 60 DAA. The highest control percentage $(50 \%)$ was observed for $M$. aegyptia. These results were reinforced upon observing the lowest percentage of biomass reduction over all tested sowing times (Fig. 6). Monquero et al. (2008b) verified that the efficacy of saflufenacil remained near $80 \%$ control of the bioindicator, even when application was followed by 28 days of drought. However, there was a marked decrease in the performance of the herbicide after this period.

According to Diesel (2014), the persistence of saflufenacil in Dystroferric Red Latosol, as determined by bioassays with cucumbers and beets, was between 25 and 35 DAA of the herbicide, which explains the low levels of control observed with time between sowing and application. These authors also found a high degree of variability in the tolerance of different bean varieties to saflufenacil.

Sowing up to 30 DAA of mesotrione resulted in the effective control of the species tested, except for $M$. aegyptia, which exhibited less susceptibility for this sowing period, and at 60 days, the highest percentage of control was observed in I. triloba (38\%). The biomass data show a reduction in the residual activity and efficacy of the herbicide throughout the tested sowing periods (Fig. 6). Mesotrione is applied at relatively low rates compared to traditional herbicides ( $\mathrm{g}$ a.i ha ${ }^{1}$ compared to $\mathrm{kg}$ a.i ha ${ }^{1}$ ) and undergoes soil dissipation in a manner similar to other herbicides by following first-order kinetics.

The residual activity of mesotrione persists during corn crop harvesting when applied at relatively low doses (100 g $\mathrm{ha}^{-1}$ ), but mesotrione is degraded before the next crop is planted, so it does not cause residual phytotoxic effects in subsequent crops (Rouchaud et al., 2000).

The lower levels of control observed after varying drought periods may be associated with herbicide loss through volatilization due to the high temperature at the soil surface, photodegradation, chemical degradation, and sorption and desorption processes, which can explain the reduced efficacy of these herbicides (Silva et al., 2007).

Our results demonstrate that species of the Ipomoea and Merremia genera have different levels of susceptibility to herbicides. When herbicides are applied during the postemergence stage, I. hederifolia, I. nil, I. quamoclit, I. triloba, and $M$. aegyptia are most sensitive to saflufenacil, and $M$. cissoides is most sensitive to tebuthiuron. The lowest susceptibility across the tested species was to imazapic, and I. triloba was the most sensitive to herbicides overall.

For herbicides applied during the pre-emergence stage, $I$. hederifolia, $I$. nil, and $I$. quamoclit are most sensitive to saflufenacil; I. triloba and $M$. cissoides are most sensitive to tebuthiuron; and $M$. aegyptia is most sensitive to amicarbazone. The lowest susceptibility across the tested species was to mesotrione, and l. quamoclit was the most sensitive to herbicides overall.

For most of the Ipomoea and Merremia species tested in this study, effective control after periods of drought occurred after 15 days for the herbicide saflufenacil; after 30 days for the herbicides imazapic, mesotrione, and tebuthiuron; after 45 days for amicarbazone; and after 60 days for sulfentrazone.

\section{Materials and Methods}

Experiment 1 - Susceptibility of different morning glory species to residual herbicides applied during the preemergence stage

\section{Site and soil}

Experiments were conducted under greenhouse conditions from June 2016 to April 2017. Experimental units were made up of polyethylene pots with a 5-L capacity were filled with Dystrophic Red Latosol (Embrapa, 2013). The results of the chemical and physical analyses of this soil can be seen in Table 1.

\section{Plant materials}

Seeds of I. nil, I. hederifolia, I. quamoclit, I. triloba, $M$. aegyptia, and $M$. cissoides were provided by Agro Cosmos Ltd. (Engenheiro Coelho - SP, Brazil). After sowing (10 seeds per pot), pots were irrigated, and herbicides were applied 24 hours later.

\section{Treatments and experimental design}

The herbicides were treated as independent experiments with a fully randomized $6 \times 6$ factorial design with six replicates of six species of morning glory (I. nil, I. hederifolia, I. quamoclit, I. triloba, M. aegyptia, and $M$. cissoides) and six doses of the herbicides tebuthiuron $(3,200 ; 1,600 ; 800 ; 400$; 200 and $0.0 \mathrm{~g}$ a.i ha $\left.{ }^{-1}\right)$, amicarbazone $(2,100 ; 1,050 ; 750$; $375 ; 187$ and $0.0 \mathrm{~g}$ a.i ha $\left.{ }^{-1}\right)$, sulfentrazone $(1,200 ; 600 ; 300$; 15075 and $\left.0.0 \mathrm{~g} \mathrm{a.i} \mathrm{ha}^{-1}\right)$, mesotrione (240; $120 ; 60 ; 30 ; 15$ and $0.0 \mathrm{~g}$ a.i ha $\left.^{-1}\right)$, saflufenacil $(200 ; 100 ; 50 ; 25 ; 12$ and $0.0 \mathrm{~g}$ a.i ha ${ }^{-1}$ ), and imazapic (360; 180; 90; 45; 22 and $0.0 \mathrm{~g}$ a.i ha $\left.{ }^{1}\right)$.

A $\mathrm{CO}_{2}$-pressurized backpack sprayer was used to apply the herbicides at a pressure of $30 \mathrm{lb}^{-2}$ through a bar containing four XR 11003 fan nozzles spaced $0.5 \mathrm{~m}$ apart. A total of 200 $L \mathrm{La}^{-1}$ of the spray mixture was consumed. Pre-emergence application of the herbicides was performed one day after the weed seeds were sown. The meteorological data at the times of herbicide application were as follows: wind speeds of $0.8 \mathrm{~m} \mathrm{~s}^{-1}$, humidity of 63.2 , and a temperature of $26.2^{\circ} \mathrm{C}$.

\section{Variables assessed}

Evaluations were performed 35 DAA. To determine phytotoxicity, a percentage grading scale was used in which 0 (zero) corresponded to no injury to the plant and 100 (one hundred) indicated plant death (ALAM, 1974). At 35 DAA, the aerial part of the plants was cut, and the weight of the dry biomass was determined by heating in a forced-air oven $\left(60{ }^{\circ} \mathrm{C}+/-2{ }^{\circ} \mathrm{C}\right)$ until a constant weight was reached. The reduction in the percentage of dry biomass relative to that of the control plants was evaluated. 


\section{Statistical analysis}

The obtained data were submitted to an analysis of variance using an F-test. Quantitative data were analyzed using nonlinear regressions with the statistical program SigmaPlot (version 10.0) from Systat Software, Inc., San Jose California USA.

Experiment 2: Effect of drought on the efficacy of residual herbicides applied in the pre-emergence stage to different species of morning glory

\section{Site and soil}

Experiments were conducted under greenhouse conditions from June 2016 to April 2017. The experimental units consisted of polyethylene pots with a 5-L capacity that was filled with Dystrophic Red Latosol soil (Embrapa, 2006). The results of the chemical and physical analyses of this soil can be seen in Table 1.

\section{Treatments and experimental design}

For each herbicide, a fully randomized $5 \times 6$ factorial design was implemented with six replicates of five durations of drought after herbicide application $(-0,15,30,45$, and 60 DAA) and six species of morning glory (I. nil, I. hederifolia, $I$. quamoclit, I. triloba, M. aegyptia, and M. cissoides). Each herbicide was used alone at the following doses: amicarbazone $\left(1,050 \mathrm{~g}\right.$ a.i ha $\left.{ }^{-1}\right)$, imazapic (180 g a.i ha $\left.{ }^{-1}\right)$, mesotrione (120 g a.i ha $\left.{ }^{-1}\right)$, saflufenacil (100 g a.i ha $\left.{ }^{-1}\right)$, sulfentrazone (600 $\mathrm{g}$ a.i ha $\left.{ }^{-1}\right)$, and tebuthiuron $(1,600 \mathrm{~g}$ a.i. $\left.\mathrm{ha}^{-1}\right)$. An application without the herbicide treatment served as the control.

Herbicides were applied at a pressure of $30 \mathrm{lb}^{-2}$ with the aid of a $\mathrm{CO}_{2}$-pressurized backpack sprayer equipped with a bar containing four XR11003 fan nozzles spaced $0.5 \mathrm{~m}$ apart, and $200 \mathrm{~L} \mathrm{ha}^{-1}$ of the spray mixture was consumed. The meteorological data at the time of application were as follows: wind speed of $2.2 \mathrm{~m} / \mathrm{s}$, humidity of $65.9 \%$, and temperature of $25.6^{\circ} \mathrm{C}$.

\section{Plant materials}

Seeds of I.pomoea nil, I. hederifolia, I. quamoclit, I. triloba, $M$. aegyptia, and $M$. cissoides were provided by Agro Cosmos Ltd. (Engenheiro Coelho - SP, Brazil). After the herbicides were applied, the pots were kept in a greenhouse with no irrigation until sowing $(0,15,30,45$, and 60 DAA). Ten seeds of each species were sown at a depth of $1 \mathrm{~cm}$ with minimal soil rotation.

\section{Variables assessed}

The effects of herbicide treatments on the plants were evaluated at 35 DAA in accordance with the visual symptoms of phytotoxicity, which involves the use of a percentage grading scale in which 0 (zero) corresponds to no injury to the plant and 100 (one hundred) indicates plant death (ALAM, 1974). At 35 DAA, the plants were cut, and the weight of the dry biomass was determined by drying in a forced-air oven $\left(60^{\circ} \mathrm{C}+/-2{ }^{\circ} \mathrm{C}\right)$ until a constant weight was reached. The biomass values for plants after herbicide treatment were compared with those of the control plants, and the \% reduction was calculated.

\section{Statistical analysis}

The resulting data were submitted to an analysis of variance using an F-test, and the means were compared via Tukey's test at the $5 \%$ level of probability using the statistical program ASSISTAT. Quantitative data were analyzed using non-linear regression via the statistical program SigmaPlot (version 10.0).

\section{Conclusion}

Ipomoea hederifolia, I. nil, and I. quamoclit were most susceptible to saflufenacil; I. triloba and $M$. cissoides were most susceptible to tebuthiuron; and $M$. aegyptia was most susceptible to amicarbazone. The effectiveness of herbicides after periods of drought began to decrease after 15 days for saflufenacil; 30 days for imazapic, mesotrione, and tebuthiuron; 45 days for amicarbazone; and 60 days for sulfentrazone.

\section{Acknowledgments}

The authors are grateful to FAPESP (Fundação de Amparo a Pesquisa do Estado de São Paulo) for financial support.

\section{References}

ALAM -Asociación Latinoamericana de Malezas (1974) Recomendaciones sobre unificación de los sistemas de evaluación en ensayos de control de malezas. 1: 35-38.

Azania CAM, Azania AAPM (2009) Plantio da cana-de-açúcar e o manejo de plantas daninhas de difícil controle. Protec. 1: $30-33$.

Blanco FMG, Velini ED (2005) Persistência do herbicida sulfentrazone em solo cultivado com soja e seu efeito em culturas sucedâneas. P Daninha. 23(2):693-700.

Bhullar MS, US, Singh S, Singh M, Jhala AM (2012) Control of morningglories (Ipomoea spp.) in Sugarcane (Saccharum spp.) Weed Technol. 26(1):77-82.

Carbonari CA, Gomes GLGC, Trindade MLB, Silva JRM, Velini ED (2016) Dynamics of Sulfentrazone Applied to Sugarcane Crop Residues. Weed Sci. 64(1):201-206.

Carvalho LB, Bianco S, Bianco MS (2014) Estudo comparativo do acúmulo de massa seca e macronutrientes por plantas de Zea mays e Ipomoea hederifolia. P Daninha. 32 (1):99107.

Carvalho SJP, Nicolai M, López-Ovejero RF, Medeiros D, Christoffoleti PJ (2006) Influência de diferentes períodos de seca sobre a eficácia do herbicida imazapic. STAB. 24(1):41-43.

Carvalho FT, Queiroz JRG, Toledo REB (2011) Eficácia do herbicida amicarbazone no controle de cordas-de-viola na cultura da cana-de-açúcar (Saccharum spp). Rev $\mathrm{Br}$ Herbicidas. 10(3):183-189.

Carvalho SJP, Ribeiro Dias AC, Hideki M, Nicolai $M$, Christoffoleti PJ (2012) Atividade residual de seis herbicidas aplicados ao solo em época seca. Rev Ceres. 59 (2):278-285 
Campos LHF, Francisco MO, Carvalho SJP, Nicolai M, Christoffoleti PJ (2009) Susceptibilidade de Ipomoea quamoclit, I. triloba e Merremia cissoides aos herbicidas sulfentrazone e amicarbazone. P Daninha. 27(4): 831-840.

Christoffoleti PJ, Carvalho SJP, López-Ovejero RF, Nicolai M, Hidalgo E, Evanil JS (2007) Conservation of natural resources in Brazilian agriculture: implications on weed biology and management. Crop Protec. 26(3): 383-389.

Christoffoleti PJ, Carvalho SJP, Nicolai M (2006) Carfentrazone-ethyl aplicado em pós-emergência para o controle de Ipomoea spp. e Commelina benghalensis na cultura da cana-de-açúcar. P Daninha. 24(1): 83-90.

Correia NM, Durigan JC (2004) Emergência de plantas daninhas em solo coberto com palha de cana-de-açúcar. P Daninha. 22(1):11-17.

Correia NM (2016) Chemical Control of Morning Glory Species in Sugarcane Harvested in the Dry and Semi-Wet Seasons. P Daninha. 34(2):333-343.

Diesel F, Trezzi MM, Oliveira PH, Xavier E, Pazuch D, Pagnoncelli FD (2014) Tolerance of dry bean cultivars to saflufenacil. Ciênc Agrotec. 38 (4): 352-360.

EMBRAPA (2013) Sistema brasileiro de classificação de solos. 3 ed. 353.

Gannon TW, Hixson AC, Keller KE, Weber JB, Knezevic SZ, Yelverton FH (2014) Soil properties influence saflufenacil phytotoxicity. Weed Sci. 62(4): 657-663.

Giancotti PRF, Toledo REB, Alves PLCA, Victória Filho R, Negrisoli E, Cason JB (2012) Eficácia de herbicidas em condições controladas para o controle de gramíneas infestantes de canaviais em estiagem Rev $\mathrm{Br}$ Herbicidas. 11(3): 269-275.

Kissmann KG, Groth D (1999) Convolvulaceae. In: BASF (ed) Plantas infestantes e nocivas, 3rd edn. BASF, São Paulo, 2.

Kuva MA, Pitelli RA, Salgado TP, Alves P (2007) Fitossociologia de comunidades de plantas daninhas em agroecossistema cana-crua. P Daninha. 25(3): 501-511.

Lucio FR, Parreira MC, Pereira FCM (2011) Controle de convolvuláceas infestantes na cultura da cana-de-açúcar. Rev Br Herbicidas. 10(3): 305-311.

Mallipudi NM, Stout SJ, Dacunha AR, LEE A (1991) Photolysis of imazapyr (AC 243997) herbicide in aqueous media. J Ag and Food Chem. 39(2):412-417.

Monquero P A, Silva PV, Silva ACH (2011) Monitoramento do banco de sementes em áreas de cana-de-açúcar colhida mecanicamente. P Daninha. 29(2):107-119.
Monquero PA, Amaral LR, Binha DP, Silva PV, Silva AC, Martins FRA (2008a) Mapas de infestação de plantas daninhas em diferentes sistemas de colheita da cana-deaçúcar. P Daninha. 26(1): 47-55.

Monquero PA, Binha DP, Silva AC, Silva PV, Amaral LR (2008b) Eficiência de herbicidas pré- emergentes após períodos de seca. P Daninha. 26(2):185-193.

Orzari I, Monquero PA, Reis FC, Sabbag, RS (2013) Germination of Convolvulaceae family species under different light and temperature conditions and sowing depth. P Daninha. 31(1):53-61.

Pagnoncelli FDB, Trezzi MM, Brum B, Vidal RA, Portes ÁF, Scalcon EL, Machado A (2017) Morning glory species interference on the development and yield of soybeans. Bragantia. 76(4):470-479.

Perim L, Toledo, REB, Negrisoli E (2009) Eficácia do herbicida amicarbazone no controle em pós-emergência de espécies de corda-de-viola (Ipomoea grandifolia e Merremia cissoides). Rev Br Herbicidas. 8(1):19-26.

Rodrigues BN, Almeida FS. Guia de herbicidas (2015) 6 ed. Londrina, 697p.

Rouchaud J, Neus O, Cools K, Buckle R (2000) Dissipation of the triketone mesotrione herbicide in the soil of corn crops grown on different soil types. Toxicol Environ Chem. 77(1):1-40.

Seefeldt SS, Jensen, JE. and. Fuerst EP (1995) Log-logistic analysis of herbicide dose-response relationships. Weed Technol. 9(2):218-227.

Silva AA (2007). Herbicidas: classificação e mecanismo de ação. In: Silva AA, Silva JF (eds). Tópicos em manejo de plantas daninhas. 1rd edn. U FV: Viçosa.

Silva PV, Monquero PA, Munhoz WS (2015) Controle em pós-emergência de plantas daninhas por herbicidas utilizados na cultura da cana-de-açúcar. Rev Caatinga. 28(1): 21-32.

Souza ELC, Foloni LL, Mantovani EC (2008) Comportamento do tebuthiuron em solo de cultivo de cana-de-açúcar utilizando lisímetro de drenagem modificado. P Daninha. 26 (1): 157-163.

Takano HK, Constantin J, Braz GBP, Oliveira RS (2015) Época seca e textura do solo afetam o controle químico de Senna obtusifolia em cana-de-açúcar. Rev $\mathrm{Br}$ Herbicidas. 14 (3):181-193.

Wichert RA, Townson JKD, Bartlett W, Foxon GA (1999) Technical review of mesotrione, a new maize herbicide. Pages 105-110 in1999 Brighton Crop Protection Conference: Weeds. Proceedings of an International Conference. Brighton, UK: British Crop Protection Council. 